\begin{tabular}{lr}
\hline U. \\
UNTERSITAS TANJUSGPURA
\end{tabular}

\title{
Need Analysis as the Foundation to Develop Supplementary Material for Tenth Grade Students
}

\author{
Tri Mulyaningsih and Yohanes Gatot Sutapa Yuliana \\ Faculty of Teacher Training and Education; Universitas Tanjungpura - Indonesia \\ three_lyani@yahoo.co.id
}

\begin{abstract}
This research used a descriptive method to explore the needs of tenth grade students in learning English writing. In order to achieve this purpose, classroom observation, questionnaire, and interview were conducted to collect the data. In addition, several related documents such as 2013 curriculum, syllabus, the current English textbook used were analyzed. The results showed that the students are in intermediate level. Moreover, they had difficulties to write in correct grammar. Furthermore, there was also a need to provide the topics related to art and culture and daily life in the language material. Malay culture became the choice of the students to be the theme of their learning material. Moreover, the learning material needed to be completed with the teacher's book which could give guidance to the teacher about the instruction or method that could be used in the classroom. Finally, the findings would be used as the base for developing the English writing material.
\end{abstract}

\section{Keywords}

Need analysis, Malay culture, writing materials

DOI: http://dx.doi.org/10.26418/jeltim.v1i1.28468

\section{INTRODUCTION}

Language learning material contributes to the success in language learning. There can be in any form such as videos, flipcharts, flashcards, filmstrips, posters and other as long as they can be used to facilitate the language leaning. However, textbook as one of language learning materials often be used during teaching learning process in the classroom as it is not only cheaper to produce but also useful to be used by lage number of learners at a time. According to Tomlinson (2012) a good material should be informative, instructional, experiential, eliciting, and exploratory. It can be said informative and instructional if it can inform the learners about the target language and can guide them in practicing the language. Furthermore, it is said experiential, eliciting, and exploratory if it is able to provide the learners with the experience of language in use, encourage them to use the language, and help them to make discoveries about the language. In brief, one should consider about those characteristics when developing language learning material for language learners.

There are two types of language material; commercial material and non-commercial (authentic) materials. Nowadays, there are many commercial English language materials easily to be found in the market. They bring several advantages such as time saving, well-organized, and the availability of teaching manual. In different circumstances, it also has lead to several possible disadvantages as it is designed for a wide user that is culturally diverse and geographically dissimilar. The culture of the English countries is different with the culture of the target culture. Besides, as Indonesia is multicultural country, the culture in one area will also be different from others areas. For instance in West Kalimantan there are even more than five different tribes with their own cultures such as Dayak, Malay, Tionghoa, Java, Bugis, etc. As a result the commercial material very often does not match the specific culture and the specific needs of paticular learners.

The language material very often discusses about four language skills; speaking, listening, reading, and writing. Among those four skills, writing is the most difficult skill to be acquired because there are many things things to be noticed when the students write in second language such as grammar, diction, spelling, and others. Besides, according to Ministry of Education and culture (2016) the goal of the English subject syllabus for senior high school is to develop students' potential in order to have communicative competence in interpersonal, transactional, and functional texts. It also concerns to improve students' ability in using English language in various tetxs. It then can be said that writing plays important role and become the concern for senior high 
school students. Under other condition, based on Permendikbud No 59 (2014) the learning load for English lesson in senior high school is very limited. As a result the teacher cannot spend sufficient time in teaching writing and leave the students by asking them to write based on the topic given without practicing. For this condition, the students have to be independent by learning by themselves outside of classroom to practice writing texts.

Dealing with the explanation above, language learning material which is suitable with the students need and context to support students writing skill should be developed. English writing materials should be developed based on need analysis to ensure that the contents effectively support the students in mastering English. In need analysis there is a process to gather information about the learners in order to find out the skills that they need to develop and the best way they can develop it. It is in line with one of the principles of materials from Tomlinson (2011) that the materials should be relevant and useful for the students. It means that the materials have to provide the information that is needed by the students and the points be taught have to be related to the students' background study and needs. It can only be done through need analysis.

Need analysis is not only for English for Specific Purpose (ESP) or vocational program. It can also be used for English for General Purpose (EGP) that usually taught in senior high school. It can be used to specify the content that meet the needs of the learners.

Need analysis is divided into two (Hutchinson and Waters (1987). They are target needs (i.e. what the learners need to do to cope in the target situation) and learning needs (i.e. what the learners need to do in order to success in the course completion). In the target needs analysis, the knowledge and the abilities that should be acquired by the learners to be able to perform well in the target situation are analyzed. Those target needs analysis are divided into necessities, lacks, and wants.

'Necessities' can be defined as the types of needs determined by the demands of the target situation. It is "what the learner has to know in order to function effectively in the target situation" (Hutchinson and Water, 1991). For the example, the linguisic features of several texts are necessary for the students to master in learning English writing.

'Lack' is defined as the gap between what the learners already know and what the learners do not know. In order to find out about the lack of the learners, the necessities of the learners should be compared to what the learners already know. On the other side, 'want' is defined as the learners expectation about the language area that they want to master.

Learning analysis is different from target analysis. In learning analysis, there is a concern about the analysis of the learners' learning needs according to their motivation, condition of the learning situation, and the learners' existing knowledge and skills. It is because in developing material, the target objective is not the only thing to be considered as it is also important to keep the students interest and motivation in English learning.

This research concerned with those needs as it tried to find about the students' necessities, lacks and wants that could be used as foundation in developing the writing material. On the other hand, student' need alone was not enough to be the base for material development. It should also meet the current curriculum used. In Indonesia, curriculum is defined as "a set of plan and regulation about the aims, content, and material of lessons and the method employed as the guidelines for the implementation of learning activities to achieve given education objectives" (UU No.20/2003). Based on the definition, education in Indonesia sees the curriculum as written guidelines for the educators to design learning activities in the classroom.

Curriculum in Indonesia has changed several times. 2013 Curriculum is the latest curriculum used in Indonesia. The 2013 curriculum is a curriculum of value which is occupied by character building. According to Mulyasa (2013, p. 7) the implementation of the 2013 curriculum is independent that learner can increase and use their knowledge, assess the value of character good morality in order they will exhibit positive attitude in their daily behavior. In this curriculum, the scope of material contains standard competencies for graduation (SKL), the core competencies (Kompetensi Inti/KI) and the basic competencies (Kompetensi Dasar/KD). By analyzing the curriculum used, the content that needs to be put in the English writing material can be identified.

Besides the students' need and the curriculum used, current textbooks used also need to be analyzed to know about the strengths and the weaknesses of the books. The weaknesses of the books need to be discovered so that it could be covered by supplementary material.

In conclusion, this research focuses the analysis into three areas namely students' need, curriculum, and textbooks analysis to find the need as a whole for the development of supplementary material

\section{RESEARCH METHOD}

\subsection{Form of Research}

As the purpose of this research was to investigate the needs of the students that can be used as foundation to develop English writing material, descriptive method was applied. "A descriptive study describes and interpret what it is" (Best, 1970). This method reported the data descriptively. In addition it was conducted through several steps namely data reduction, data display, and drawing conclusion. 


\subsection{Participants of Research}

In this research the participants referred to the students and teacher. In total there were 26 tenth grade students, one English teacher of of SMAN 1 Kubu Raya academic year 2017/2018.

\subsection{Technique of Collecting the Data}

There were several techniques of collecting data used for this research. First, it was interview. Semi structure interview was used by preparing some questions before interviewing. It was also recorded. Second, it was questionnaire. In this research the questionnaire was used find out the students' needs and wants. From the questionnaire the researcher got the description of the students' need which could be used to develop writing materials that were relevant to the students. The criteria of the questionnaire were adapted from some experts such as Hutchinson and Waters (1987), and Nunan (2004). Third was observation. Students' direct observation was used during the teaching learning process in the classroom.

\subsection{Tools of Collecting the Data}

There were several tools used to collect the data. First was interview guideline. The interview guideline was used to get the data from the teacher to find out his opinion about students need in teaching and learning process. Besides, it was used to know the teacher's belief about a good English material for the students. The interview was in the form of semi structured interview. Second, it was questionnaire sheet. The questionnaire was a combination of closed and open-ended questionnaire which was made based on the intended criteria of students' need. It was in the form of multiple choice item and short answer questions. Third was observation guide. For finding out the students' need, the researcher used rating form observation guide from Chesterfield (1997, p. 49).

\section{RESEARCH FINDINGS AND DISCUSSION}

\subsection{Findings}

The first step in this research was intended to find out about the students need. The need of tenth grade students was identified by distributing close-ended and open-ended questionnaire, interview with the English teacher, and class observation

Based on data from questionnaire, interview, and observation, the students' need analysis which was divided into target need and learning need could be described in three aspects; cultural aspect, educational aspect, and English Language Teaching aspect.

In educational aspect, there was a need to provide the material that appropriate to their level. Their writing skill level was intermediate where they only had limited number of vocabulary and had a weak grammatical skill. It could be seen in table 3 that $77 \%$ of students admitted that they were in the intermediate level.

Those were caused by less frequency in writing which was only twice a week as stated in the questionnaire that more than $80 \%$ of students accepted that they seldom write.

\begin{tabular}{|c|c|c|c|c|}
\hline No & Questions & Items & $\mathbf{N}$ & $\%$ \\
\hline \multirow[t]{3}{*}{1.} & \multirow[t]{3}{*}{$\begin{array}{l}\text { The level of my } \\
\text { writing ability is ... }\end{array}$} & $\begin{array}{l}\text { a. Beginner } \\
\text { very limited number of vocabulary, very weak grammatical } \\
\text { skill, sentence pronunciation is still influenced by the mother } \\
\text { tongue. }\end{array}$ & 6 & $23 \%$ \\
\hline & & $\begin{array}{l}\text { b. Intermediate } \\
\text { the number of vocabularies is quite limited, the grammatical } \\
\text { skill is weak enough, the sentence pronunciation is quite } \\
\text { influenced by mother tongue. }\end{array}$ & 20 & $77 \%$ \\
\hline & & $\begin{array}{l}\text { c. Advance } \\
\text { Able to use appropriate vocabulary, good grammatical ability, } \\
\text { and clear pronunciation. }\end{array}$ & 0 & $0 \%$ \\
\hline \multirow[t]{3}{*}{2.} & \multirow{3}{*}{$\begin{array}{l}\text { The level of frequency } \\
\text { to write in English is ... }\end{array}$} & a. Often (More than 3 times a week) & 4 & $15 \%$ \\
\hline & & b. seldom ( 2 times a week) & 21 & $81 \%$ \\
\hline & & c. never & 1 & $4 \%$ \\
\hline
\end{tabular}

Table 1: Students' Need

This writing problem was also explained by the English teacher during interview. He said that the students have weaknesses not only in vocabulary but also in writing skill.
They cannot acquire the skill of writing without practicing intensely. They need English material that can help them to practice writing not only in the classroom but also outside of the classroom. 


\begin{tabular}{|l|l|}
\hline Researcher & What kind of difficulties that the students have in learning English? \\
\hline Teacher & $\begin{array}{l}\text { The difficulty is the students lack of knowledge about English especially vocabulary } \\
\text { and in writing skill }\end{array}$ \\
\hline
\end{tabular}

Table 2: Interview with teacher

Furthermore, in English learning, students' desire about the specific topic that they want to learn to support their writing skill cannot be avoided. In the following statement about the input before writing, the students were allowed to show their preference by giving response more than one.

The result of the questionnaire showed that some of the students expected to get explanation about types of text and the structures before they learn about one specific text.
More than $40 \%$ of students chose "c" as their preference. The other $37 \%$ of students wanted to get explanation about vocabularies which are often be used in writing a text. Besides, $22 \%$ of students needed to get explanation about appropriate grammar to be used in their writing text. It means that the students still wanted to recognize about types of text before they learn about vocabulary and grammar. All of them can be given before the students writing a text so that the students would get knowledge in writing text correctly based on the genre.

\begin{tabular}{|l|l|l|c|c|}
\hline No. & \multicolumn{1}{|c|}{ Questions } & \multicolumn{1}{|c|}{ Items } & $\mathbf{N}$ & $\%$ \\
\hline 3. & $\begin{array}{l}\text { Before writing English } \\
\text { text I want to get } \\
\text { explanation about .... }\end{array}$ & $\begin{array}{l}\text { a. appropriate grammar to be used in the following writing } \\
\text { text. }\end{array}$ & 10 & $22 \%$ \\
\cline { 3 - 6 } & & $\begin{array}{l}\text { b. vocabularies which are often be used in writing text. } \\
\text { written. }\end{array}$ & 17 & $37 \%$ \\
\cline { 3 - 5 } & & 19 & $41 \%$ \\
\hline
\end{tabular}

Table 3: Students' Wants

The information about what the students want to learn is not complete without knowing about the students' lack. The statement in the following table asked about the learning difficulty that students had. In this statement, the students could give more than 1 answer based on their real condition. Even though in question number 3 the grammar became the last choice that the students wanted to learn in English, in number 4 most of the students express their difficulty in using correct grammar. It could be shown that there were $41 \%$ of students answered " $d$ " to state their difficulty in grammar. Furthermore, $27 \%$ of students assumed that difficulty in choosing appropriate vocabulary were their problem in learning English. The rest of them assumed that their problem in learning English were arranging paragraphs and composing sentences. Only 1 student had other problem that was not mentioned in the options. The supplementary material later would be designed to solve those kind of problems.

\begin{tabular}{|l|l|l|c|c|}
\hline No. & \multicolumn{1}{|c|}{ Questions } & \multicolumn{1}{|c|}{ Items } & N & $\%$ \\
\hline \multirow{4}{*}{4.} & $\begin{array}{l}\text { My difficulties in } \\
\text { learning English is ... }\end{array}$ & a. Difficulty in composing sentences. & 4 & $10 \%$ \\
\cline { 3 - 5 } & & b. Difficulty in choosing appropriate vocabulary. & 12 & $27 \%$ \\
\cline { 3 - 5 } & & c. Difficulty in arranging paragraph. & 9 & $20 \%$ \\
\cline { 3 - 5 } & & d. Difficulty in using correct grammar. & 18 & $41 \%$ \\
\cline { 3 - 5 } & & e. Other & 1 & $2 \%$ \\
\hline
\end{tabular}

Table 4: Students' Lack

Based on the analysis in educational aspects, there were several things to be noticed. First, the writing material had to be compatible with students' need such as students' level and students' ability. Second, it had to be able to cover the student' desire about one specific topic that should be included in their learning material. In this case, vocabulary and grammar explanation cannot be separated from writing skill. It was not because the students want to get this kind of input but also because the students have difficulty in those areas which then affect their ability in writing skill. Third, the writing material for the students should be able to help them to use language effectively in writing.

The next point to be discussed is the analysis in educational aspect. In this aspect it is important to get the information about how the students learn English especially for writing skill. Based on the data from the observation it was known that the teaching learning process in the classroom still adopt traditional classroom method.

The teacher only explained in brief and the students just listened to the explanation passively without giving any response. If there were questions from the students, it was only about how many paragraphs they had to write and when they had to submit it. Sometimes the teacher asked simple recall questions and some close ended questions related to the topic in the book which were answered with simple answers by the students.After the teacher explained, the students were asked to write text based on the topic given by the teacher. As the time was so limited, the students had to continue writing at home and submit it in the next meeting 


\begin{tabular}{|l|l|l|l|}
\hline \multicolumn{1}{|c|}{4} & \multicolumn{1}{|c|}{3} & \multicolumn{1}{c|}{2} & \multicolumn{1}{c|}{1} \\
\hline $\begin{array}{l}\text { Teacher uses more than } \\
\text { 2 teaching methods, all } \\
\text { involve learners. }\end{array}$ & $\begin{array}{l}\text { Teacher uses 1 or 2 } \\
\text { methods that involve } \\
\text { learners. }\end{array}$ & $\begin{array}{l}\text { Teacher uses 1 or more } \\
\text { methods that do not } \\
\text { involve learners. }\end{array}$ & $\begin{array}{l}\text { Teacher uses method } \\
\text { that does not involve } \\
\text { learners. }\end{array}$ \\
\hline
\end{tabular}

Table 5 : Use of a variety of teaching methods

During the teaching learning process, the teacher became the controller of learning. He spent a lot of time explaining rather than giving the students opportunity to be involved in critical and creative thinking activities such as discussion or sharing ideas with peers. It is more like teacher-centered where the students are expected to be able to write just by listening to the explanation about how the sentences are formed.

The characteristics of traditional classroom can also be seen from how the students do the task during teaching learning process. there was no grouping during teaching and learning process as they did their work individually.

\begin{tabular}{|l|l|l|l|}
\hline \multicolumn{1}{|c|}{4} & \multicolumn{1}{|c|}{3} & \multicolumn{1}{c|}{2} & \multicolumn{1}{c|}{1} \\
\hline $\begin{array}{l}\text { Learners involved in } \\
\text { discussion and problem- } \\
\text { solving and/or creative } \\
\text { activities. }\end{array}$ & $\begin{array}{l}\text { Learners involved only } \\
\text { in sharing of ideas. }\end{array}$ & $\begin{array}{l}\text { Learners involved in } \\
\text { teacher-directed } \\
\text { activities. }\end{array}$ & $\begin{array}{l}\text { Teacher lecturers, } \\
\text { learners listen to } \\
\text { teacher. }\end{array}$ \\
\hline
\end{tabular}

Table 6: Critical and Creative Thinking Activities

For the learning activity in the classroom, it can be adjusted to the students' preference. The students do not want to do the activities individually as most of them
There were no discussion about the problems, questions, and activities.

The only activity that students did in the classroom was reading the standard competencies that should be achieved loudly before they listened to the teacher's explanation.

For this reason, there is a need to provide the writing material which completed with the teacher's guide so that the teacher can also get input for the variety of teaching method and writing activities that can be used in the classroom. prefer to do it in small group. It means that in developing the writing material, the content should provide the content that can be done individually and in small group.

\begin{tabular}{|l|l|l|c|c|}
\hline No. & \multicolumn{1}{|c|}{ Questions } & \multicolumn{1}{c|}{ Items } & N & $\%$ \\
\hline \multirow{2}{*}{16.} & In teaching and learning & a. individually & 6 & $19 \%$ \\
\cline { 3 - 5 } & $\begin{array}{l}\text { process, you prefer to do } \\
\text { the task or activity .... }\end{array}$ & b. in pairs & 6 & $19 \%$ \\
\cline { 3 - 5 } & & c. in small group & 19 & $59 \%$ \\
\cline { 3 - 5 } & & d. in big group & 1 & $3 \%$ \\
\cline { 3 - 5 } & & e. other. & 0 & $0 \%$ \\
\hline
\end{tabular}

Table 7: Setting

Grammar and vocabulary are included in the aspects of writing besides content and the organization. As the students have difficulty in using correct grammar and choosing correct vocabulary for their writing, several activities for those areas also had to be considered carefully. As can be seen in the table, only few students chose remembering sentence structure as one of the activities to solve their problem in grammar for their writing. They more preferred to directly make sentences based on the topic. It was possible to be done by not giving the rule of the grammar directly.

\begin{tabular}{|c|c|c|c|c|}
\hline No. & Questions & Items & $\mathbf{N}$ & $\%$ \\
\hline \multirow[t]{5}{*}{11.} & \multirow{5}{*}{$\begin{array}{l}\text { What kind of activities } \\
\text { do you want in learning } \\
\text { grammar? }\end{array}$} & a. Doing grammar test. & 12 & $25 \%$ \\
\hline & & b. Making sentences based on the topic. & 16 & $33 \%$ \\
\hline & & c. Identifying and correcting wrong sentences. & 11 & $23 \%$ \\
\hline & & d. remembering sentence structure. & 8 & $17 \%$ \\
\hline & & e. other. & 1 & $2 \%$ \\
\hline \multirow[t]{2}{*}{12.} & & a. matching words with the meaning provided. & 16 & $33 \%$ \\
\hline & & b. completing sentences or paragraph. & 12 & $25 \%$ \\
\hline
\end{tabular}

They can start the activity by analyzing the sentences in discourse level which make the learning process becomes more meaningful and the rule becomes memorable. After they discover the rule, the teacher can explain more about it or they can read the clearer explanation about it in the English writing material. That is why there is a need to provide grammar discussion to give valuable input on how they use the language in written text. It does not only provide the explanation of the grammar but also tell the students how to use it in sentences which ater enhance their understanding 


\begin{tabular}{|l|l|l|c|c|}
\hline \multirow{2}{*}{$\begin{array}{l}\text { What kind of activities } \\
\text { do you want in } \\
\text { increasing vocabulary? }\end{array}$} & $\begin{array}{l}\text { c. identifying and translating new vocabularies from the } \\
\text { text. }\end{array}$ & 15 & $31 \%$ \\
\cline { 2 - 4 } & d. finding meaning on dictionary. & 5 & $11 \%$ \\
\cline { 2 - 5 } & e. other. & 0 & $0 \%$ \\
\hline
\end{tabular}

Table 8: Procedure

For the activity that relate to vocabulary, most of the students declared that they want to match the words with the meaning provided. It implies the need to add vocabulary session where the students can find the difficult vocabulary and then try to match it with the meaning provided. Same as the grammar part, the vocabulary meaning should not be given directly as the students should try to identify the meaning by reading the text first before they find out its meaning.

Based on the previous description it can be said that the students need to have writing material that facilitate students' learning process by providing variety of model of texts, contextual grammar and vocabulary, and manageable unit.

\begin{tabular}{|c|l|l|c|c|}
\hline No. & \multicolumn{1}{|c|}{ Questions } & \multicolumn{1}{|c|}{ Items } & N & $\%$ \\
\hline \multirow{3}{*}{10.} & \multirow{2}{*}{\begin{tabular}{l} 
Writing topics that I \\
\multirow{2}{*}{ want are ... }
\end{tabular}} & a. Topics related to daily life. & 16 & $35 \%$ \\
\cline { 3 - 5 } & & b. Topics related to art and culture. & 22 & $48 \%$ \\
\cline { 3 - 6 } & & c. Topics related to science and technology. & 8 & $17 \%$ \\
\cline { 3 - 6 } & d. Other. & 0 & $0 \%$ \\
\hline
\end{tabular}

Table 9: Topic of Writing

For this topic preference, the students specifically prefer to discuss about Malay art and culture because most of them was bounded to Malay ethnic identity. There was more than half number of students chose Malay culture for their topics of writing even though Malay was not the biggest population in west Kalimantan.

This cultural topic preference was not intended to show the superiority of one specific culture and discrimination to other cultures, but it more used to show tolerance for multiculturalism in west Kalimantan.

There are several ethnics in West Kalimantan such as Malay, Dayak, China, Jawa, and many others. The choice of Malay culture to be the content of the writing material was not because of the personal ethnicity feeling from the students' preference, but because of the more specific reason that the writing material are going to be used in West Kalimantan which has Malay culture as part of the society.
In cultural aspect, there was a need to provide the topics related to art and culture and the topics related to daily life. It was shown from the following table that majority of students want the topics that relate to art and culture. Besides, in the second place, they also still want the topic that relate to daily life where they have experience on it.

It means that their English writing material should include anything about art and culture, and daily life to attract the students' interest. The art and the culture should be close with the students' experience and daily activities. Those preferences could be seen in the following table.

\begin{tabular}{|l|c|c|}
\hline \multicolumn{1}{|c|}{ Culture } & $\mathbf{N}$ & $\mathbf{\%}$ \\
\hline Melayu & $\mathbf{1 4}$ & $\mathbf{5 6 \%}$ \\
\hline Dayak & $\mathbf{4}$ & $\mathbf{1 6 \%}$ \\
\hline Jawa & $\mathbf{5}$ & $\mathbf{2 0 \%}$ \\
\hline Bugis & $\mathbf{0}$ & $\mathbf{0 \%}$ \\
\hline Cina & $\mathbf{0}$ & $\mathbf{0 \%}$ \\
\hline Madura & $\mathbf{2}$ & $\mathbf{8 \%}$ \\
\hline Other & $\mathbf{1}$ & $\mathbf{4 \%}$ \\
\hline
\end{tabular}

Table 10: Students' culture preference

The cultural content of writing material can be supported with the relevant pictures to enhance their understanding about the content. It is as stated in their preference about the input they need for writing that can be seen in the following table

\begin{tabular}{|c|c|c|c|c|}
\hline No. & Questions & Items & $\mathbf{N}$ & $\%$ \\
\hline \multirow[t]{5}{*}{6.} & \multirow{5}{*}{$\begin{array}{l}\text { The input you want in } \\
\text { writing is ... }\end{array}$} & a. Giving the article from internet. & 7 & $14 \%$ \\
\hline & & b. showing relevant pictures. & 22 & $46 \%$ \\
\hline & & c. Completing incomplete text. & 11 & $23 \%$ \\
\hline & & d. arranging paragraphs in good order. & 8 & $17 \%$ \\
\hline & & e. Other. & 0 & $0 \%$ \\
\hline
\end{tabular}

Table 11: Input 
Based on previous need analysis description, there were several things which should be noticed. First, since the students were weak in writing skill the reading text had to be provided as a model of writing. As a result, there was a need to provide the reading texts which were interesting and had the element of local art and culture around them without touching upon ethnicity problem. These reading texts would be great input for the students about how the language worked and how to write based on genre. Second, the cultural content in the writing material should be accurate and current. It means that the information about Malay culture provided in their material should be new and detail. Third, the cultural readings also had to be interesting, significant, and appropriate with the age level. The existence of relevant picture in the writing material can make the writing material become more interesting which then can provoke their motivation in learning.

The second step after finding out about the students' need was document analysis. The document analysis was executed to know about the supporting information such as 2013 curriculum, syllabus and current textbook used in order to get more description about what really needed to be put in the English writing material.

Curriculum analysis was needed as guidelines for the teaching and learning process to achieve certain educational objective. Besides, it contained the information about the core competence, basic competence, and load time of learning that must be followed by the students. This information will give benefit in organizing the writing material that matches with the curriculum used.

The curriculum used by most of public schools in west Kalimantan was 2013 curriculum (K 13). 2013 curriculum was a curriculum of values that occupied by character building. The values could be tracked from the core competence which was designed by Ministry of Education and Culture. There were four core competences (KI) which were designed for spiritual competence (KI 1), social competence (KI 2), knowledge competence (KI 3) and developing skill (KI 4). For the development of the materials, the information in $\mathrm{KI} 3$ and $\mathrm{KI} 4$ became the focus.

In the syllabus of curriculum 2013, the tenth grade students would learn about 3 types of text. They were recount text, narrative text, and descriptive text. They were stated in basic competence (KD) which became the reference to develop achievement indicator.

Besides curriculum analysis, there was also textbook analysis. Textbook analysis was done to get the information about the strengths and the weaknesses of the books. The weaknesses of the books need to be discovered so that it could be covered by supplementary material. The textbooks mostly used were Pathway to English and English book from Ministry of Education and culture.
First analysis was the appropriateness with curriculum 2013. Pathway to English did not write the core competence and basic competence explicitly. On the other hand the English book from Ministry of Education and culture stated it clearly only in the teacher's book so that the students did not know it. On the other hand both of them stated the purpose of learning. It would be better if the core competence, basic competence and purpose of learning were stated explicitly in both teacher's book and the students' book.

Second analysis was about the guide book usage. Pathway to English did not provide the teacher's book or any guide book to maximize the usage of the book. On the other side, book from Ministry of education and culture has both teacher's book and student's book. There was clear explanation about the learning activity such as learning procedure, instruction, and time. However, it still did not give clear guidance for both the teacher and the students since the content of teacher's book was different from student's book. It is better if the teacher's book not only has the same content with the student's book but also gets additional information about the learning procedure or learning instruction. In addition both of the textbook did not give guidance about how to use the student's book or what the function of each part. So, it is better to provide the user guide in order to make the student understand about what they can find in the book.

Third was about the color and the picture. The color was very limited as the color was only black, white, and sometimes blue or pink. The textbooks become less attractive for the students as each page looked same. In addition, the picture did not really represent the content and students' culture. In Pathway to English, most of the pictures were taken from clipart or Wikipedia which were not familiar for the students. Contrarily, the English book from Ministry of Education and Culture had several illustrations about the content even though the photographs about the events around students were very few.

The last was about writing section. There were four skills discussed in the textbook but this research limited the analysis to writing skill only. Based on analysis, those textbook did not provide guidelines that could be followed by the students in order to master writing skill. Mostly the students were only asked to construct sentences or short paragraphs without scaffolding to guide them in completing the task. On the other hand, scaffolding was very important to bridge learning gap between what the students had learned and what they were expected to know and be able to do. As a result, the textbooks could not support the students to develop ideas in writing.

Those weaknesses had to be improved and covered by other supplementary material in order to support the textbooks in the teaching and learning process especially writing skill. 


\subsection{Discussion}

Writing skill is not something that can be mastered without practicing as there are several aspects need to consider such as content, organization, vocabulary, purpose, and spelling. In order to master writing skill, the students need suitable writing material which is able to support and guide them in composing good writings text. The suitable writing material has to be compatible with the students' need.

The compatibility between English material and the students' need is important because it can give reliable information on the learners' variable such as learning preference, the goal, the language ability, etc (Graves, 2000). Besides, it is a useful tool to really know what the learners actually need from supplementary material. The importance of material development based on the needs of the students became the main interest for some researcher (Hutchinson and Water, 1987; Tomlinson, 2011; Graves, 2000). It also becomes the concern of this study as the purpose of this research was to find out about the students' need that can be used as the base for developing English writing material.

Based on the finding, it was revealed that the students had limited number of vocabulary and weak grammatical skill which affect their ability in writing. In Grabe and Kaplan's taxonomy of language knowledge, vocabulary is one of linguistic knowledge which is involved in writing (Weigle, 2002, p.30). It means that vocabulary plays important role in the quality of writing as the students need to use the words correctly to express their idea in their writing. Same as vocabulary, grammar also has an important role in wriitng skill. In order to be able to communicate in a written form successfully, the students should be able to put their ideas into coherent sentences. Therefore, errors in grammar and appropriate vocabulary can prevent the students in having good writing skill.

Aside of vocabulary and grammatical problems, lack of practicing was also identified as the factor that affect the students' wriitng skill. Myles (2002) stated that writing is the skill that needs learning and practicing. Showing less effort by rarely practicing writing impact to poor writing skill. As a solution for this behavior the students needed a writing material that can be used for self-study and in the school where they could transfer their knowledge without loosing their interest.

Interest can enhance students' learning by leading the students to have better performance and achievement. It can even promote attention, recall, task persistence, and effort (Hidi, 1990). Besides, knowing about students' interest made it is easier to design suitable writing material for them. Based on the finding the students preferred to have the topics related to art and culture, and daily life.

In designing learning material, it is not enough to only find out about the students' need. It is because the material design has to match with the curriculum used by the school (2013 curriculum) as it defines the content, the skill, and values to be taught. It is in line with Nunan's idea (1998) that materials should be contextualized to the curriculum they are intended to address. As a result there is a need to provide the content of learning material that match with the core competence and basic competence of 2013 curriculum.

\section{CONCLUSION AND SUGGESTION}

This research is used to gather useful information that can be used to be the foundation to develop English learning material which is not only suitable with the students and the context but also match with the curriculum used in Indonesia.

The results have informed that the students need English material that can support their writing skill. In supporting their writing skill, the reading text and the explanation about types of text have to be included. Besides, it should be completed with the grammar and vocabulary information as they also lack for knowledge in those areas.

In addition the data give information that the reading texts used have to represent local art and culture around them. Kalimantan Malay art and culture can be chosen as a theme for the learning material. However, it still has to match with the core competence and basic competence of 2013 curriculum that is used by most of the schools in Indonesia.

It is suggested that the development of English learning material should follow the need of the students, the context, and the curriculum used.

\section{REFERENCE:}

Best, J. W. (1970). Research in Education. New Jersey: Prentice Hall and Englewood Cliff.

Chesterfield, R. (1999). Classroom Observation Tools. USAID: IEQ.

Depdiknas. (2003). Undang-Undang Nomor 20 tahun 2003 tentang Sistem Pendiidkan Nasional. Jakarta: Depdiknas.

Graves, K. (2000). Designing Language Courses: A Guide for Teacher. New York: Heinle\&Heinle.

Hidi, S. (1990). Interest and Its Contribution as a Mental Resources for Learning. Review of Educational Research, 60, 549-571.

Hutchinson, T. \& Waters, Alan. (1987). English for Specific Purposes. Cambridge: Cambridge University Press.

Hutchinson, T. \& Waters, Alan. (1991). English for Specific Purpose: A Learning Centred Approach. Cambridge: Cambridge University Press.

Kemendikbud. (2016). Silabus Mata Pelajaran Sekolah Menengah Atas/Madrasah Aliyah/Sekolah Menengah Kejuruan/Madrasah Aliyah Kejuruan (SMA/MA/SMK/MAK). Jakarta: Kemendikbud.

Mulyasa. (2013). Pengembangan dan Implementasi Kurikulum 2013. Bandung: PT. Remaja Rosdakarya.

Myles, J. (2002). Second Language Writing and Research: The Writing Process and Error Analysis in 
Student Texts. The Electronic Journal for English as a Second Language, 6(2).

Nunan, D. (1988). Principles for Designing Language Teaching Materials. Guidelines, 10(2), 1-24.

Nunan, D. (2004). Task-Based Language Teaching. Cambridge: Cambridge University Press.

Permendikbud. (2014). Peraturan Mentri Pendidikan dan Kebudayaan Republik Indonesia Nomor 59 Tahun 2014 Tentang Kurikulum 2013 Sekolah
Menengah Atas/ Madrasah Aliyah. Jakarta: Departemen Pendidikan dan Kebudayaan.

Tomlinson. (2011). Materials Development in Language Teaching (2nd Edition). Cambridge: Cambridge University Press.

Tomlinson. (2012). Materials Development for Language Learning and Teaching. 143-179.

Weigle, Sara Cushing. (2002). Assessing Writing. New York: Cambridge University Press 
